See discussions, stats, and author profiles for this publication at: https://www.researchgate.net/publication/341000965

The post-Marxist political economy of EU trade. A discourse-theoretical analysis of the construction of political agency in the European Parliament

Preprint $\cdot$ April 2020

CITATIONS

0

1 author:

Thomas Jacobs

Ghent University

9 PUBLICATIONS 14 CITATIONS

SEE PROFILE
READS

66 


\title{
The post-Marxist political economy of EU trade. A discourse-theoretical analysis of the construction of political agency in the European Parliament.
}

\author{
Thomas Jacobs, Ghent University, Korte Meer 1, Ghent, 9000, Belgium. T.Jacobs@UGent.be
}

\begin{abstract}
The objective of this paper is to demonstrate the value of a post-Marxist and discourse-theoretical approach to the role of ideas in political economy, via a case study of the trade politics of the European Parliament. The ontological monism of postMarxist Discourse Theory is proposed as a functional alternative to constructivism and its separation of ideas and discourse into two distinct ontological categories, which has dominated the critical EU trade policy literature thus far.
\end{abstract}

The argument is structured in two parts. The first part is theoretical in nature. It outlines the ontological differences between a constructivist and a post-Marxist approach to the study of neoliberalism in EU trade politics, and discusses the analytical advantages of the latter. Specifically, it is argued that post-Marxism facilitates a more sophisticated and nuanced analysis of political agency under neoliberalism, by emphasizing the articulated character of neoliberal policies - thereby avoiding the common pitfall of subsumption.

The empirical second part draws on the 'logics framework' and corpus-linguistic methods to operationalize this post-Marxist approach. It examines the discursive construction of political agency in the Parliament's plenary debates on international trade, and finds a consensus within the Parliament regarding the importance of politicians in the governance of markets. This observation contradicts the classic Marxist account of neoliberalism as involving the decline of political agency. However, further examination shows that this consensus broke down during the controversy over the TTIP agreement (2013-2016). The replacement of an 'economic' by a 'democratic antagonism' as the dominant counterhegemonic political logic is a potential explanation for this collapse in self-confidence, which in turn has important politico-strategic implications.

Keywords: Laclau, poststructuralism, post-Marxism, political economy, European Union, European Parliament, Discourse Theory, discourse, international trade 
Despite its seemingly self-evident nature, it took a long time for the insight that "ideas matter in politics" to conquer the hearts and minds of scholars of EU trade policy. De Ville and Siles-Brügge lament that "ideas, where they appear, are often treated as a residual, explaining variation where the primary variables have not made sufficient in-roads." ${ }^{1}$ Yet while they are right to complain that ideas all too frequently receive the Cinderella treatment from political economists, a small village of indomitable constructivists holds out. Inside its walls, a substantial literature that pays ample attention to how political actors think and talk about international trade, has flourished. This paper constitutes an intervention into this small but blossoming subfield.

\section{PART 1: a Post-Marxist Approach to the Role of Ideas in Political Economy}

The main thrust of this strand of literature is critical in nature, as it is marked by a consensus regarding the deeply neoliberal nature of EU trade policy. ${ }^{2}$ But apart from their critical inclination, many contributions to this subfield also share an interesting ontological characteristic: they take the neoliberal inspiration of EU trade policy to be a feature of the individual or collective actors implementing that policy. ${ }^{3}$ Ideas are understood in this literature as being held by people such as politicians, policy-makers, and public officials, or by institutional actors such as "the EU", "the Commission", "the Council", or "the Parliament". The ideational world, in other words, is conceived as the subjective lifeworld of the political agents. ${ }^{4}$

This theoretical inclination is indebted to Vivien Schmidt's Discursive Institutionalism ${ }^{5}$ and Colin Hay's related Constructivist Institutionalism. ${ }^{6}$ Building on a Habermasian conception of discourse, both of these approaches promote a reciprocal but disjoining definition of ideas and discourse. ${ }^{7}$ Ideas are defined as the consciously conveyed or unwittingly constructed content of discourse, while discourse functions as the vessel through which an actors communicate and exchange their conscious and unconscious ideas. ${ }^{8}$ This 
definition clearly postulates ideas and discourse as ontologically separate and distinct: the former functions on an ideological plane where meaning is constituted; the latter operates on a communicative plane where pre-constituted meaning is transmitted. ${ }^{9}$

In line with its Habermasian roots, the study of ideas via Discursive Institutionalism puts a lot of emphasis on the actors' communicative action and their personal agency, to the point of flirting with "the danger of assigning too much space to individual abilities to change institutional structures." 10 By underscoring very strongly how actors shape the ideational world with their discursive interventions, Discursive Institutionalism leaves itself vulnerable to the charges of voluntarism and methodological individualism. ${ }^{11}$ Institutions risk losing their "stickiness", ${ }^{12}$ as they "dissolve [...] into the conscious ideas of individuals", ${ }^{13}$ resulting in a world where society changes at the whim of the imagination the moment actors think up an alternative way of organizing the social world.

Indeed, many empirical studies of the role of ideas in EU trade policy explicitly stress that they are "agent-centred", ${ }^{14}$ and focus their constructivism on how actors seek to change and influence the world through personal communicative interventions. We know for instance that officials of the European Commission's DG Trade sometimes formulate their ideas in a strategic and even disingenuous manner, and that they adapt their discourse to the situation at hand in order to boost the prospects of their neoliberal ideas. ${ }^{15}$ Similarly, it has been shown that the neoliberal core of EU trade policy can be re-articulated in a variety of ways, in order to safeguard it from challenges and criticisms. This happened in the wake of the financial crisis, ${ }^{16}$ the TTIP protests, ${ }^{17}$ Brexit, and the aggressive mercantilist trade strategy of the U.S. under Donald Trump. ${ }^{18}$ Research on the rhetoric of former EU Trade Commissioner Lamy, who linked the naked neoliberalism of his predecessor and successors with an emphasis on the need to "manage" and "harness" globalization, points in a similar direction. ${ }^{19}$ What all of these analyses share from an ontological point of view, is that they see discourses as created 
and composed by actors, who use them to communicate their own ideas and realize their personal worldview. This particular "understanding of 'the discursive' overemphasizes the autonomy of reflexive agents' ideas and actions as well as their usefulness in explaining change. ${ }^{20}$

This paper shares the commitment of the extant constructivist literature to heeding the crucial role that ideas play in political economy, but it argues for an alternative conceptualization of ideas, which does not divorce ideas and discourses into two separate ontological categories, and therefore does not risk voluntarism. This way, it encourages a theoretical diversification of the study of ideas in politics, opening up a novel approach that facilitates research designs inaccessible to a more conventional constructivism. Concretely, it proceeds by building on the work of a number of political theorists who have suggested that post-Marxist Discourse Theory (PDT) could provide the groundworks for a functional alternative to Discursive Institutionalism. ${ }^{21}$ The key difference between DI and PDT is

\footnotetext{
"that ideas and meaning are ontologically speaking of a subjective nature in DI and of an intersubjective nature in [P]DT. From an agency perspective, this means a subject holds ideas in DI, whereas ideas are the structural positions subjects can occupy in [P]DT." ${ }^{22}$
}

Put differently, ideas are primarily intersubjective in nature for PDT, and subjectivity is a function of inscription into intersubjective subject positions. For DI, this is the other way around: ideas are primarily subjective in nature, and only become intersubjective when they are communicated discursively. By suspending the difference between 'ideas' and 'discourses' and going from idealism to discursive materialism, PDT moves meaning and ideas from the subjective to the intersubjective level. ${ }^{23}$

Crucially, such a post-Marxist approach would allow us to think about ideas as discursive all the way through, eliminating the need for an extra-discursive sphere ontologically constituting ideas before that are discursively communicated. ${ }^{24}$ In doing so, 
PDT facilitates a move beyond actors' personal interests and intentions,${ }^{25}$ decentring the deliberate actions of the subject in favour of an approach that sees discourses as structural and relational. ${ }^{26}$

Particularly the poststructuralist interpretation of the theory of hegemony upon which PDT is founded, is productive in this regard. It would allow us to recast discourses and ideas from the personal properties of independent subjects into intersubjective structures with their own logics and their own ontological finality, and from which agents derive their subjectivity through identification and inscription. ${ }^{27}$ Put differently, the poststructuralist interpretation of the theory of hegemony replaces the study of the wilful and deliberate manipulation of ideas with the analysis of ideational constellations that provide the strategic context for action. ${ }^{28}$

The ultimate point of such a 'poststructuralist institutionalism' is to allow the formulation of research questions that lie beyond the purview of a constructivist approach. The case study that finishes this paper, for instance, analyses the logic of how political agency is articulated in the neoliberalism-dominated trade politics of the European Parliament, in a way that is inaccessible to non-poststructuralist ontologies. However, in embracing PDT and the poststructuralist turn, this paper definitely does not seek to repudiate the constructivism that has so far dominated ideational approaches to EU trade policy. Poststructuralist approaches cannot be considered better or more correct than constructivist approaches and vice versa - they merely answer different research questions, put different emphases, focus on different mechanisms. With that in mind, this plea for PDT is most certainly not a plea against constructivism, it is merely a plea for theoretical pluralism. One should not pick poststructuralism over constructivism (or vice versa) because it is better, but because it answers different questions and satisfies different research interests. 


\section{Neoliberalism and Political Agency}

As already briefly mentioned, this paper will attempt to demonstrate the added value of a discourse-theoretical approach to ideas via a study of the discursive construction of political agency in EU trade policy. The traditional Marxist interpretation associates neoliberalism with the withdrawal of the state from society and the decline of political agency. ${ }^{29}$ However, by facilitating an analysis of the discursive structures that constitute the very idea of political agency, a post-Marxist approach provides us with the tools to nuance and complicate this picture. Furthermore, it does so without necessitating recourse to a universal category of neoliberalism, thus dodging the trap of subsumption prevalent in the neoliberalism literature. As such, the following case study provides us with a clearer picture of how the idea of political agency is articulated within the framework of a hegemonic neoliberalism in the context of the European Parliament, while showing on a theoretical level how a discourse-theoretical framework makes possible research designs that are outside the scope of a constructivist approach.

Concretely, this case study is concerned with how European politicians - specifically europarliamentarians (MEPs) - think and talk about their capacity to shape international markets. What affects their (dis)belief in this capacity? To what evolutions and political dynamics is it subject, and what consequences do these evolutions have? I want to figure out how MEPs discursively constitute their own ability to act and intervene in the economy and the society around them during parliamentary debates; how this ability to act is part of the conditions of possibility and impossibility for particular politico-economic projects; ${ }^{30}$ and how this ability and the structural set of strategic conditions it provides, can be changed.

Political agency and the capacity of politicians and citizens to achieve changes in the economy and in society as a whole, is of course a classic site of contemporary political struggle. Neoliberalism's hegemonic status for decades allowed it to claim that "there is no alternative", thus denying the idea that alternative modes of economic governance could ever 
be beneficial or even imaginable. ${ }^{31}$ Through "the removal of control over economic policy from elected officials and forums, the closure of social and political spaces for deliberation on the economy, and the denial of political agency", markets were freed from political meddling. ${ }^{32}$ The economic organization of society was thus 'depolicitized' and vanished as a governmental responsibility or the object of democratic decision-making. ${ }^{33}$ The agency of politicians and the state receded while the agency of global corporations and markets grew so goes the Marxist interpretation of neoliberal globalization. ${ }^{34}$

However, despite the fact that this classic interpretation of neoliberalism as antipolitical and anti-state is omnipresent in the contemporary public debate, it is by now wellestablished that neoliberal politics can just as well involve the active use of the state to create, institute, drive, and maintain free markets in particular realms of the social world. This alternative account of neoliberalism - often inspired by a Foucauldian perspective - sees neoliberalism as a particular way of governing markets, a mode of governance that can take various forms, and that stands next to other potential modes of economic governance. ${ }^{35}$ As such, it is not a universal, "monolithic" mechanism unfolding uniformly around the globe, ${ }^{36}$ but rather a complex, variegated process whose characteristics and features are always mutating, contested, and locally translated. ${ }^{37}$

One of those polyvalent and contested characteristics is of course precisely the notion of political agency, as the decline of political agency is not an inherent and unchanging feature of neoliberalism, but a precarious and contingent idea, ${ }^{38}$ that manifests itself in some forms of neoliberalism, but not in others. While the "agency of both state and capital is embedded within a nascent neoliberal common sense", this common sense and its social construction of political agency are ever "open to political contestation." 39 This is of course where the research questions formulated above come in: I want to study the structural position of political agency within the "nascent neoliberal common sense" dominating the European 
Parliament, and analyse its articulation as well as its contestation in this specific context. However, by opting for a discourse-theoretical approach, rather than a Foucauldian or a constructivist one, it also hopes to overcome a problem that has been plaguing the neoliberalism literature: the issue of subsumption.

\section{Subsumption and the Study of Neoliberalism}

Subsumption is the problem that occurs when the explanation of a phenomenon through its classification as an instance of neoliberalism conceptually overstretches the notion 'neoliberal' while simultaneously leaving the phenomenon under analysis underdetermined. ${ }^{40}$ Put differently, subsumption happens when cataloguing a particular situation as 'neoliberal' fails to do justice to both the subtleties of that situation and to the notion of neoliberalism itself. Even when trying to acknowledge the variegated manifestations of neoliberal governance, the tendency in various literatures, including the Foucauldian and the constructivist one, to return to a larger meta-narrative about neoliberalism subsumes specific neoliberal moments into "an impossible object" that "only exists... as an effort to construct

that impossible object." ${ }^{41}$ Rose et al. pose the problem aptly when they discern "a tendency to identify any program with neoliberal elements as essentially neoliberal, and to proceed as if this subsumption of the particular under a more general category provides a sufficient account of its nature or explanation of its existence." ${ }^{42}$

To render the issue of subsumption more concrete, let us return for a moment to the critical EU trade policy literature. The free trade agreements the EU attempts strikes with developed countries and the trade deals it concludes with developing countries today have both been characterized as 'neoliberal'. ${ }^{43}$ But of course, this does not mean that the legal, economic, and political modalities of the EU's economic relation with Canada, Vietnam, and East Africa are identical, nor do the scholars using the term imply this. The concrete forms and shapes assumed by these commercial relations differ in various important ways, but they 
have certain features and properties that all allow them to be characterized as 'neoliberal' albeit in different ways. However, if one (mis)understands 'neoliberalism' as a reified and unchanging category, one risks obscuring the nuances and differences in how neoliberal patterns materialize in each of these cases.

Phelan was the first to theorize the problem of subsumption with regards to the literature on neoliberalism. ${ }^{44}$ Building on the theoretical work of Glynos and Howarth, ${ }^{45}$ he characterizes subsumption as an exaggerated concern with the universal, at the expense of the particular. In the quest to find universal or quasi-universal causal laws and mechanisms whose validity transcends the concrete contexts in which they are found, social scientists fall into the trap of overreliance on generalization. ${ }^{46}$ Reminiscent of the natural sciences, such analyses construct explanations by aggregating phenomena as instances of a higher-order process. ${ }^{47}$ With regards to neoliberalism, this manifests itself as an "overly reductive use of a necessarily reductive term", as neoliberalism morphs from the thing that "needs to be explained" into the thing that "does the explaining.," their work is done when they found something they can justifiably call 'neoliberal'. This renders the term neoliberal vague and overstretched, while failing to provide an appropriate account of the situation at hand.

Phelan argues that the 'logics framework', the most common way of operationalizing PDT, can help us avoid the pitfall of subsumption. He recommends that in order to avoid the "excessive use of the reified category of neoliberalism", we "speak of neoliberal and neoliberalized logics that are always contextually articulated with other political, social [...] logics", rather than of a monolithic and stale neoliberalism. ${ }^{49}$ By understanding neoliberalism as a logic, a pattern that renders the practices it comprises possible, intelligible, and vulnerable ${ }^{50}$ we can maintain the concept of neoliberalism without losing track of how it is concretely and contextually articulated. Practically, this entails that we need to study of how 
particular contexts facilitate neoliberal political patterns, and how neoliberal politics convince, win, work, "tick" within these contexts. ${ }^{51}$ Through the conceptualization of neoliberalism as a logic that only exists in concrete and articulated moments, the reification of neoliberalism as a universal category and the trap of subsumption are avoided.

Returning once more to the politics of EU trade to illustrate this, it has for instance been shown that while neoliberal ideas have dominated the EU's trade policy for the past 25 years, the concrete articulation of this neoliberalism has varied and changed over time, depending on the political context in which it found itself. 'Free trade' has over time been combined with 'embedded liberalism', 'fair trade', and 'trade as foreign policy' discourses, in order to safeguard the neoliberal core from various challenges and to expand its scope of applicability. ${ }^{52}$ Once we realize that all of these articulations constitute distinct and unique political patterns, which, while every one of them displays neoliberal features, do not necessarily aggregate into instances of a universal neoliberalism, we will have dodged the trap of subsumption.

This is of course where the case study outlined above comes in: if we want to avoid the pitfall of subsumption and refrain from reifying neoliberalism, studying how political agency is conceived within specific politico-economic situations is paramount. Understanding the contextual articulation of neoliberalism and grasping why neoliberal logics thrive in a particular setting, necessitates an understanding how political agency is articulated within that context. The shape assumed by neoliberal politics is deeply intertwined with how its subjects perceive their capacity to affect the world and the economy around them. In many situations, the prevailing understanding of agency will be found to align with the classic account of neoliberalism that associates neoliberalism with a receding belief in political agency. But we will see that in the European Parliament, this is in fact not the case. As such, if we want to understand how neoliberalism functions as a worldview within the European Parliament and 
how it manages to dominate its policy-making, studying the particularities of how political agency is articulated in this context will be absolutely crucial.

Given that this paper wants to demonstrate the added value of a post-Marxist and poststructuralist approach to ideas in political economy, it is crucial to underline that the research question laid out here cannot really be cogently answered from a constructivist point of view - it in fact can't even be coherently formulated within a constructivist paradigm. The conceptualization of political agency as a logic within a hegemonic neoliberal regime of thought does not strictly speaking fit within a constructivist ontology. Belief in political agency is an idea, and ideas are according to Discursive Institutionalism fundamentally subjective in nature. ${ }^{53}$ The discursive communication of an idea is therefore something personal and individual. People can share a belief in or a scepticism towards collective agency, but the idea itself remains the subjective propensity of the agent. This makes a discursive-institutionalist ontology excellent for understanding how actors formulate their own understanding of political agency. It facilitates the study of how politicians actively deny agency in order to promote their preferred neoliberal recipes, ${ }^{54}$ or reversely claim it to maintain their legitimacy in crisis situations. ${ }^{55}$

But if we want to think of political agency as something more than a belief shared by subjects - as an object of collective investment, a structural logic, an intersubjective structure - then a theoretical framework that provides a coherent account of intersubjectivity is needed, and post-Marxist Discourse Theory provides such an account. ${ }^{56}$ This reasoning also explains why discursive-institutionalist approaches share a tendency towards subsumption that poststructuralist ontologies such as PDT's do not exhibit: the division between discourse and ideas in DI creates a separate ontological realm where neoliberalism can exist outside of concrete, discursively articulated patterns, as a pure and universal category into which concrete discursive manifestations can be subsumed. By merging discourse and ideas into one 
ontological category, PDT precludes this possibility, thus removing the risk of subsumption. Hence, constructivist and poststructuralist paradigms serve different analytic goals, and facilitate different research designs.

\section{PART 2: the discursive construction of political agency in the European Parliament}

To recapitulate, the point of departure of this paper is that the study of political economy in general, and the study of EU trade policy in particular, have gotten serious about the role of ideas and discourse in politics thanks to a Habermas-inspired constructivism. My wager is that although such a perspective has proven to be very valuable indeed, a tremendous amount of unexploited analytical potential remains contained within alternative theorizations of the ideational and the discursive, notably within post-Marxist Discourse Theory. Therefore, I set out to demonstrate the value of a post-Marxist perspective on political economy through a study of the discursive construction of agency in debates about commercial policy during the plenary sessions of the European Parliament. Not only is this a type of question that a more traditional constructivist approach would struggle to conceive, and does the postMarxist approach cope better with the dangers of subsumption and reification, the issue of political agency is also at the core of contemporary debates about neoliberalism.

The rest of my argument will proceed in three steps. First, I will specify the research question elaborated above by zooming in on the specifics of the case at hand - laying out the data I used, the particular analytical framework I opted for, and the method I used to apply that approach to the data. In the second step, I will show the results of this case study, which I will use to reflect on the value of a post-Marxist approach to ideas in political economy in the conclusions. 


\section{Theory, Data, and Method}

The framework of post-Marxist Discourse Theory that used in this paper finds its origins in the work of Ernesto Laclau and Chantal Mouffe and was further developed via the logics approach of Glynos \& Howarth. ${ }^{57}$

PDT's core assumption is the poststructuralist principle that society is not build on a single fundamental and determinative principle of organization. Neither the nation nor class nor any other set of norms can form the definitive basis or the ultimate ground for social structuration. This entails that all social structure is radically contingent. Whichever way society is organized, it could perfectly have been organized differently. Hence, social structure cannot be essentialized or reified. It is impossible for a figment of social structuration to exhaustively capture the world around us by perfectly implementing the fundamental principles on which this world is built, as PDT denies that such principles exist. Any structure is thus 'dislocated': imperfect, replaceable, and non-necessary in nature. Whatever social forms that do exist, are therefore the product of 'hegemony'. As no social form has any foundational ground, any object that does appear to us as a positive 'moment' within the world around us, claims this status based on its dominance over and the elimination of alternative forms of possible structuration. This leads to PDT's famous claim regarding the ontological primacy of "the political' ${ }^{58}$ : the world around us is the result of an ever-raging hegemonic struggle.

Many different frameworks have been proposed to theorize this hegemonic struggle, but the most successful to date are undoubtedly the logics of critical explanation advanced by Jason Glynos and David Howarth. ${ }^{59}$ The concept of a logic, which was already touched upon when discussing how a discourse-theoretical approach can help the literature on neoliberalism to avoid the pitfall of subsumption, refers to the capture, description, and interpretation of discursive patterns. ${ }^{60}$ A logic describes what makes a particular practice work and tick, what gives it its identity, its apparent essence. Logics come in many varieties; the two used in this 
paper are 'political' and 'social logics'. Political logics describe the contestation and countercontestation of social norms and principles; they capture the struggle over what is considered normal, common sense. Patterns that are experienced by all their subjects as normal and commonsensical, finally, are captured by social logics. Of course, normal patterns can become controversial, and vice versa. Political logics that transform into social logics lead to 'depoliticization', while social logics transforming into political logics lead to 'politicization'. 61

The following analysis also draws on the work of Glyn Daly, who has formulated the broad outlines of a discourse-theoretical approach to political economy. At the centre of his argument stands PDT's assertion that the economy as a discursive structure always contains a surplus of meaning. ${ }^{62}$ PDT contends, according to Daly, ${ }^{63}$ that any attempt to constitute the economy as a separate societal domain, distinct from other aspects of social life and governed by its own exhaustive and self-sufficient laws and rules, is bound to fail to achieve the universality and completeness it pursues. The traces of this dislocation are usually sedimented and depoliticized, thus giving rise to the classic modernist view of the economy as the foundation of society and of economics as a science. ${ }^{64}$ But by firmly positing the political and contingent character of economic forms, PDT allows reactivate these sedimented formations and to focus on the hegemonic politics that simultaneously institute and render vulnerable the economy as an apparently objective structure. ${ }^{65}$ This way, it facilitates reflection on why economic forms exist as they do, how they may be subverted, and how their contestation, recomposition, and transformation could be successful. ${ }^{66}$

Daly's insistence on the radically political and discursive dimension of economic organization is precisely the attitude this paper seeks to bring to the analysis of the European Parliament's trade politics. The manner in which members of the European Parliament (MEPs) understand their role in the governance of global markets is bound to take the form of 
a sedimented norm, a task whose outlines appear as common sense to the subjects executing it. But PDT spurs the analysis to depart from the assumption that the way in which MEPs see themselves as having or lacking political agency in the management of international trade is neither natural nor firmly grounded in extra-discursive institutional arrangements. Instead, it is to be understood as a deeply socialized logic that can nevertheless be politicized at any point. By offering this perspective, PDT expedites the study of ideas as macro-level intersubjective structures.

The data I used to study the social and political logics governing the hegemonic conception of political agency in the European Parliament (EP) are drawn from the Parliament's plenary sessions. More precisely, I compiled a corpus containing the verbatim transcripts of all plenary speeches and interventions that referred to international trade between September 1979 and May 2018. This corpus was explored via methods from computational linguistics, more specifically topic modelling.

An extensive discussion of corpus linguistics and topic modelling is unfortunately beyond the scope of this paper. Briefly, topic modelling uses an algorithm to group words that feature together in and are simultaneously absent from the same text, into clusters ('topics'). Under the right parameters, these topics can be designed to contain groups of words that render each other meaningful by constituting each other's horizon of signification - in other words, they contain discourses. ${ }^{67}$ Topic modelling allocates every word in every text to a topic, while simultaneously calculating the odds that a particular topic is represented in a random text by a particular word. Re-iterating this process thousands of times allows the algorithm to propose the topic model that best represents and summarizes the corpus.

The outputs of this procedure that are useful to empirical text analysis, are a list of the words representing each topic (allowing us to make sense of a topic), a detailed annotation of the corpus allocating every word in every text to a topic (allowing us to study a topic in 
context), and an overview of which weight every topic carries within a particular text (allowing for the corpus-wide analysis of a particular topic). When these outputs are combined with the meta-data attached to every text (the party of the speaker, the moment of the speech), topic modelling can be used to study discursive evolutions diachronically or factionally. ${ }^{68}$

\section{The Social Logic of Political Agency in the European Parliament}

Upon reading through the 250 topics in the model, ${ }^{69}$ only one topic's contents related clearly and straightforwardly to the issue of political agency. I interpreted this topic, which also happened to be the largest topic in terms of size, as containing a discourse that affirms political agency and the ability of politicians to make a difference. The following 20 terms are most likely to represent this topic (numbered \#235) in the corpus:

$235 \quad 0,22018$ must need ensure order essential believe system necessary effective guarantee needs particular support provide market balance better able conditions enable

It should be obvious at first sight why I deemed this topic to be crucial to an account of the discursive construction of political agency. Words like "support", "provide", "able", "believe", "guarantee", "conditions", and "enable" all refer to and build on a possibility for political action and intervention, whereas words like "need", "essential", "necessary", "must", "ensure", and "needs" all refer to the necessity that something be done. Initially, all key words in the topic thus seem to relate directly to the core interest of this paper: how politicians conceive of their own agential capacity. It appears that the topic expresses a logic of political action that identifies the necessity or the possibility for intervention.

In order to confirm this interpretation, I confronted it with the actual texts, so as to verify that my conclusion that this topic contains an affirmative and explicit sentiment of political agency corresponds to what was actually said during the EP plenaries. In other 
words, I checked if my interpretation of this cluster of words as dealing with the issue of political agency survived a reading of the texts in which these words actually appeared in context. To do so, I looked up the speeches in which this topic was strongly present (over $30 \%$ of the total lemmas allocated to this topic), and zoomed in on the sentences in which this topic was particularly strongly present. Those sentences indeed appeared to articulate the logic I expected them to voice:

“[...] we MEPs believe that it [the FTA] really cannot come into force until we have obtained robust guarantees, guarantees that must, [...] It will therefore be up to us - to you and to us - to ensure the proper implementation of these mechanisms in order to protect the European economy [...] However, that should not in any case exonerate us from strategic thinking in two areas. Firstly, in order to guarantee that competition is genuinely fair, $[\ldots]$ That is an essential requirement. My second point is that Europe must finally provide itself with the instruments necessary [...]."

"I welcome this resolution because the agreement reached is a particularly important guarantee of stable and reliable trade relations [...] trade conditions will also be improved. It should be noted that it is unprecedented for the EU to be managing a third country's export quota, establishing a framework for the functioning of this system in future." $" 11$

"President, the European Community has produced early results [...], first by setting land aside $[\ldots]$, secondly by reducing prices $[\ldots]$, and thirdly by opening up the EC markets $[\ldots]$ In this way the EC has made its contribution [...] we need to find an effective rebalancing mechanism that will ensure that [...] EC agricultural production must be protected from the outside in such a way as to ensure the maintenance $[\ldots]$ Fourthly, market access must be regulated in a flexible manner to ensure that [...]."72

"[...] we therefore have to make every effort to ensure that food prices are regulated and accessible to all, [...] the Commission must adopt a new trade and development strategy which would give developing countries greater independence in solving the issue of rising food prices. [...] we need to create a favourable support and business environment [...] we must restrict industrial farming activities that may have a negative impact on food production capacities. We must make every effort to ensure that greater support is 
given to development $[\ldots]$ Only by implementing measures to prevent concentration $[\ldots]$, can we limit the rise in food prices. [...] we must establish an independent regulatory agency and ensure that food safety systems work properly and effectively at regional and local levels." 73

"We should indeed establish all the elements that guarantee consumers a high level of protection $[\ldots]$. They must feel sure that their rights are fully and equally respected everywhere. In order to achieve this high level of protection, it is therefore vital to involve representative consumer organisations $[\ldots] .{ }^{.74}$

\begin{abstract}
"It continues to be the Union's job to remove the structural barriers which trade liberalisation and the open markets are facing. We need to harness the benefits of globalisation to increase employment and raise our citizens' living standards [...] The Community's job is to provide workers with appropriate, effective support enabling them to access [...] Rapid, effective help is required [...] But to ensure that this programme can provide a real panacea, a suitable budget is necessary [...]." 75
\end{abstract}

In every single one of these quotes, significant political agency is attributed by the speaker to him or herself or to the institutional actor he or she identifies ("we MEPs", "the EU”, "the European Community", "the Commission", "the Union”, "[t]he Community"). Of course, this agency is interpreted, appreciated, and constructed differently. In the first quote, it is construed negatively, as the MEP is threatening to use her agency to undo something. In the second quote, the EU's agency is deemed to be too great, the EU has in fact too much power. In the third and fourth quote, political agency is to be used for protectionist purposes, in the fifth quote, it is to be used for democratic purposes, in the sixth quote, it is put in service of greater liberalisation. But all of these quotes clearly express the capacity for political actors to intervene, to regulate, and to take action when it comes to the governance of international markets. Which form and which direction that governance needs to assume is of course the subject of great disagreement, but the fact that this governance is at all times possible is not. Regardless of whether markets are being accessed, barriers are being pulled down, trade relations are being guaranteed, production is being protected, or instruments for production 
capacity management are being provided, the discourse contained in topic \#235 expresses the belief that politicians have a crucial role to play. This entails that both protectionist and free trade policies depart from a political embedding of markets.

It thus seems fair to conclude that words featuring in topic \#235 participate in the articulation of a discourse that contains a logic of political agency. Whenever this logic is invoked, it appeals to the possibility or even the necessity for politicians to actively govern international markets and to affect their dynamics. What shape this governance ought to take and what effects it should strive for, is not a moment of this discourse. This depends entirely on the political logics that accompany the invocation of this logic, which only expresses the possibility or necessity for such governance.

Crucially, this underdetermination does not constitute a structural recognition of the contingency of these political logics - it does not explicitly acknowledge that what "needs" to be done, what is "essential" and "necessary", and what it is to "enable", is entirely open. Topic \#235 does not make "an opening to another (ethical) mode of being."76 It merely expresses an institutional confidence in the agency of parliaments, governments, and politicians, and is bereft of a more fundamental belief in human or democratic agency - in our capacity as a demos to control our own faith and shape the society we live in. The logic of political agency in the European Parliament thus entails a belief in small-p politics, in the role and power of institutions, rather than in the Political in the Laclauian sense of the word. ${ }^{77}$

What is more, several things suggest that this logic of political agency can be characterized as a social logic, which is accepted as normal, true, and common sense across time and across all corners of the political debate. The quotes offered above stem from different periods and from a variety of political affiliations. Additionally, looking at how often various political groups draw on topic \#235, we see no big outliers either. While some use it more frequently than others, all political groups feel comfortable using these discursive 
elements and the logic they compose (see table 1). The usage of topic \#235 over time fluctuates fairly little as well (see graph 1). All we see is a very slow and steady increase over several decades (compare to graphs 4,5 , and 6), the only real significant event in the timeline being an extreme drop in the middle of the current decade. This is in line with what we expect from a sedimented discourse: it functions as a stable norm. Together, these observations lend credence to the claim that topic \#235 is indicative of a discursive pattern that can be described with a social logic.

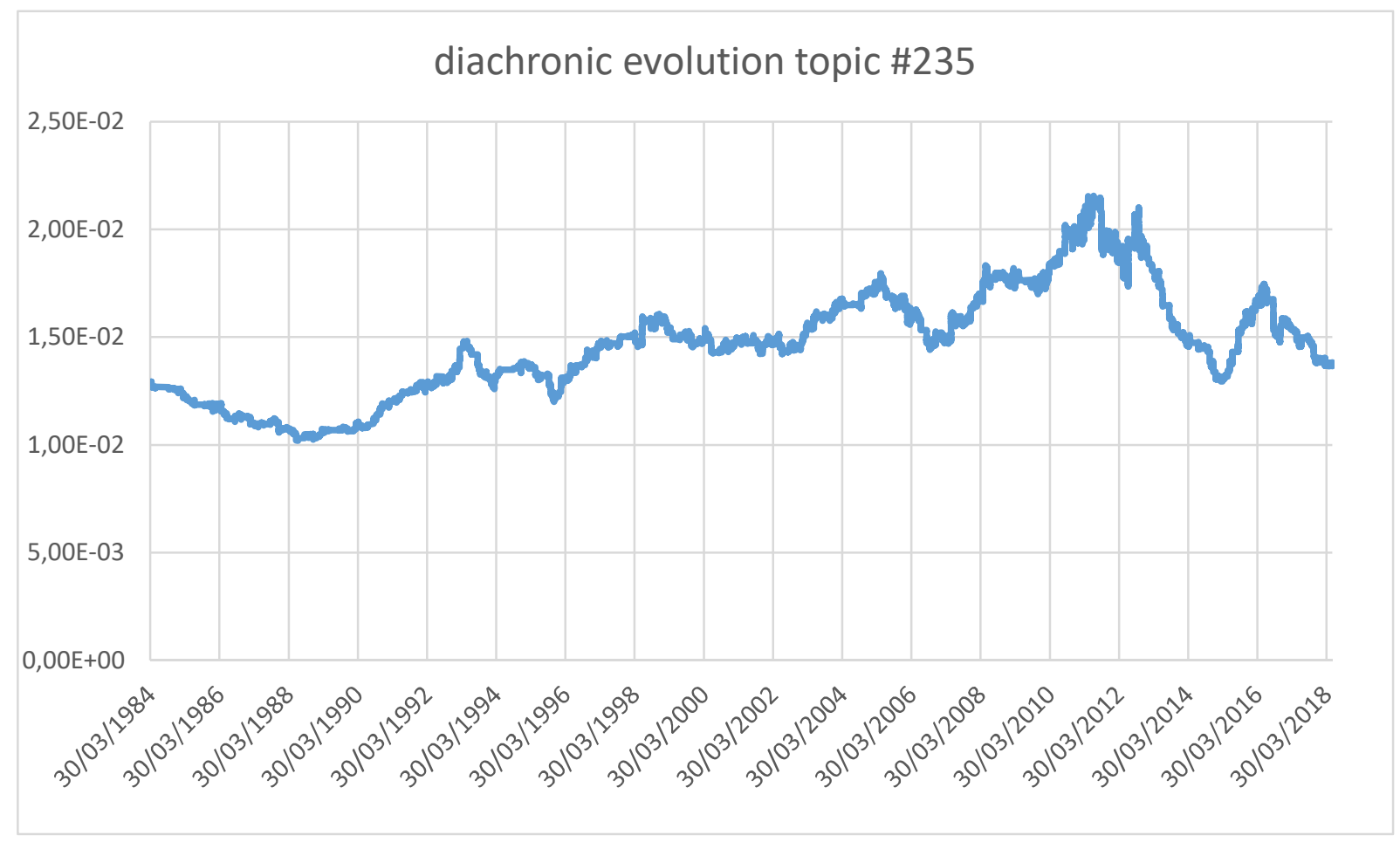

Graph $1^{78}$ : the diachronic evolution of the social logic of political agency (topic \#235)

These findings are very interesting in the light of the status quaestionis on neoliberalism discussed earlier, as the logic of political agency found in the context of the European Parliament differs completely from the classic Marxist interpretation that links neoliberalism with the denial of political agency. ${ }^{79}$ In the European Parliament, there is instead an explicit acknowledgment by both the opponents and the proponents of neoliberal 
policies that these policies are the product of political action. Neoliberal reforms such as the creation of global markets, the liberalisation of economic sectors, and the reduction of obstacles to free trade are recognized across the political spectrum as active political interventions. Markets are not perceived as spontaneous and natural phenomena, but as political artefacts.

This account demonstrates very pointedly Phelan's contention that a poststructuralist and discourse-theoretical approach can reveal the contextual nuances in how neoliberal policies are articulated. It shows how PDT facilitates a non-essentialist perspective that dodges the pitfall of subsumption, as it allows us to analyse the specificities of a particular, concrete, and situated manifestation of neoliberalism. As indicated at the start of this paper, the interpretation of political agency as a structural logic of the EP's discourse, rather than as the subjective idea or viewpoint of one or more MEPs (which would be in line with the extant literature), is in fact rendered possible by the substitution of a discursive-institutionalist for a poststructuralist perspective.

It is important to underscore that the status of the logic of political agency as a social logic, of course does not entail that political agency goes uncontested. The opposite is true; it is highly likely that the corpus features a plethora of political logics attacking this social logic. As can be seen in the second quote above, the social logic of political agency can be conceived negatively and constructed as unwanted, obsolete, or even harmful. The politicization of the social logic of political agency is in fact the subject of the next section. But even in such articulations, the apparent reality that this political agency exists, is accepted as a point of reference, which is what renders the logic of political agency into a social logic.

\section{The Politicization of Political Agency}

Returning to graph 1, which shows the diachronic evolution of topic \#235, I haven't commented yet on its rather eventful tail end. While there are few noteworthy jumps and 
drops in the timeline of topic \#235 prior to 2010, the histogram becomes far less smooth and steady after 2010. A brief drop in the usage of topic \#235 around the end of 2011 and the beginning of 2012, which is almost immediately undone, is followed by a very drastic fall between 2013 and 2015 that brought the topic to its lowest usage in over 20 years. Another brief recovery ensues in the second half of 2015, and before a renewed decline sets in at the start 2016. This decline is particularly intense during the summer of 2016, and continues into 2017. These events are completely out of line with the trend we observed prior to 2010, which showed little else than very slow and barely interrupted growth.

Neither of these three drops is very hard to interpret, as all three coincide with periods when EU trade policy was the subject of intense controversy. First, the end of 2011 and the beginning of 2012 marked the row over the Anti-Counterfeiting Trade Agreement (ACTA), which was intended to establish an international legal framework against counterfeiting and copyright infringement. The European Parliament and an international conglomerate of social movements warned of the threat the agreement's text posed to civil liberties and complained about a lack of civil society involvement, a lack of transparency in the negotiations, and a lack of political accountability. ${ }^{80}$ Secondly, the period between 2013 and 2016 saw the most heated strife over EU trade policy thus far, as a broad coalition of social movements, political parties, NGOs, and civil society organizations protested the Transatlantic Trade and Investment Partnership (TTIP), a prospective free trade agreement between the United States and the European Union. ${ }^{81}$ In the aftermath of the TTIP controversy, a similar agreement between the EU and Canada (CETA) also drew widespread opposition. ${ }^{82}$ 


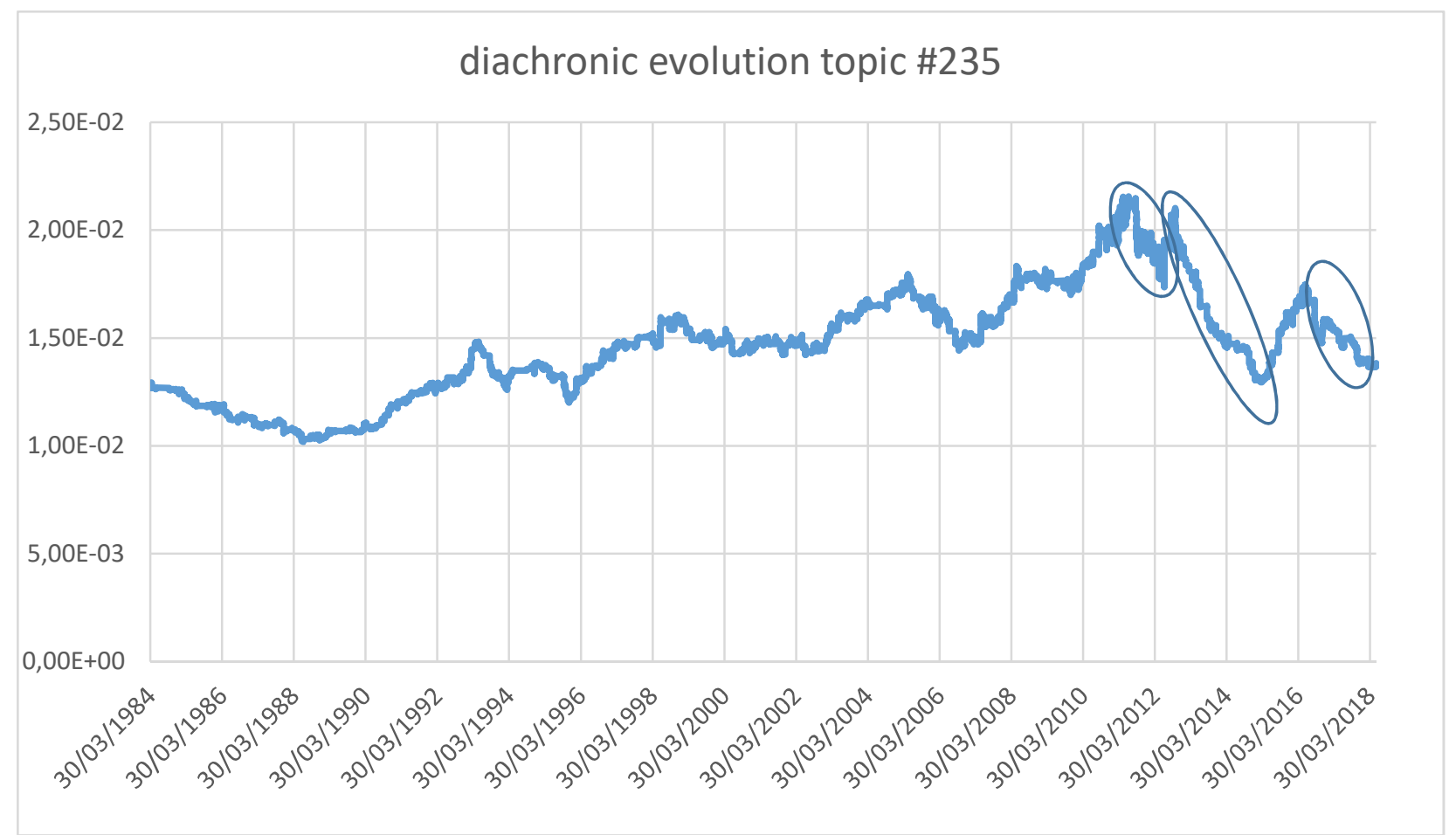

Graph 2: the diachronic evolution of the social logic of political agency (topic \#235) (ACTA, TTIP, CETA).

This leads to a second interesting empirical conclusion: the social logic of political agency weakens when the articulation of a host of political logics successfully politicizes the order of discourse of EU trade policy. In non-discourse-theoretical terms: belief in political agency in the European Parliament declines in times of crisis, a decline which took historical proportions during the TTIP controversy. 


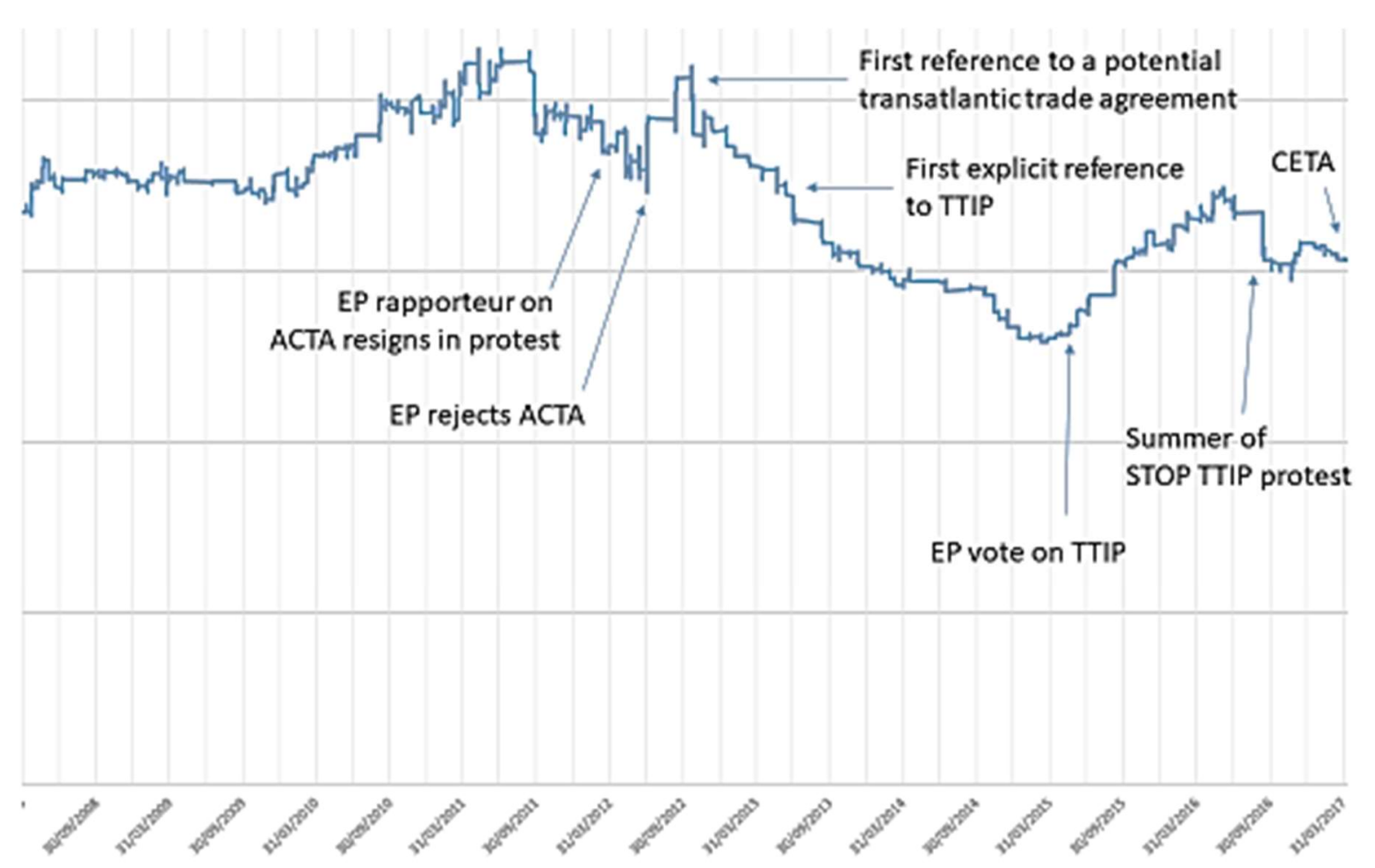

Graph 3: the politicization of the social logic of political agency during the TTIP protests

Although it may sound self-evident that the idea of political agency recedes in times of crisis, this is not necessarily the case. The counterhegemonic political logics articulated around ACTA, TTIP, and CETA, which politicized the social logic of political agency, could easily have been countered by defensive political logics safe-guarding the norm political agency. During the contestation of TTIP and CETA, such a defensive political logic indeed materialized. Simultaneous with the decline of the shared norm of political agency contained in topic \#235, a more combative yes-we-can-style discourse formulating a political logic of political agency rose, as is witnessed by the double spike of topic \#234.

2340,07567 people need europe citizens new jobs create better future want across deliver opportunity global opportunities economy growth help sure best

Terms like "create", "need", "help", and "sure" are indicative of a belief in political agency similar to the one contained in topic \#235. However, terms like "want”, “deliver", "opportunity", and "opportunities" indicate that the discourse contained in topic \#234 has a 
clear aspirational character - making it differ distinctly from the discourse in topic \#235, which presented political agency as a fait accompli. Hence, while the discourse in topic \#235 contains a social logic, the one in topic \#234 contains a political logic. The coincidence of the former's decline and the latter's growth, as well as the latter's concrete use in the corpus, suggest that the latter's political logic constituted an attempt to salvage the former's social logic. This defensive political logic proved largely unsuccessful, however. It could not salvage TTIP, nor the decline in the social logic of political agency contained in topic \#235. Unlike topic \#235, it was also never used in any meaningful quantity by the parties opposed to TTIP (see table 1).

\begin{tabular}{|l|l|}
\hline Party & Use of topic \#234 (as share of the corpus) \\
\hline ALDE & 0,013752 \\
\hline ECR & 0,024897 \\
\hline EFDD & 0,011396 \\
\hline ENF & 0,007029 \\
\hline EPP & 0,010409 \\
\hline G/EFA & 0,007501 \\
\hline GUE/NGL & 0,004709 \\
\hline independents & 0,014218 \\
\hline S\&D & 0,012933 \\
\hline
\end{tabular}

Table 1: use of topic \#234 between 1/2013 and 5/2018. 


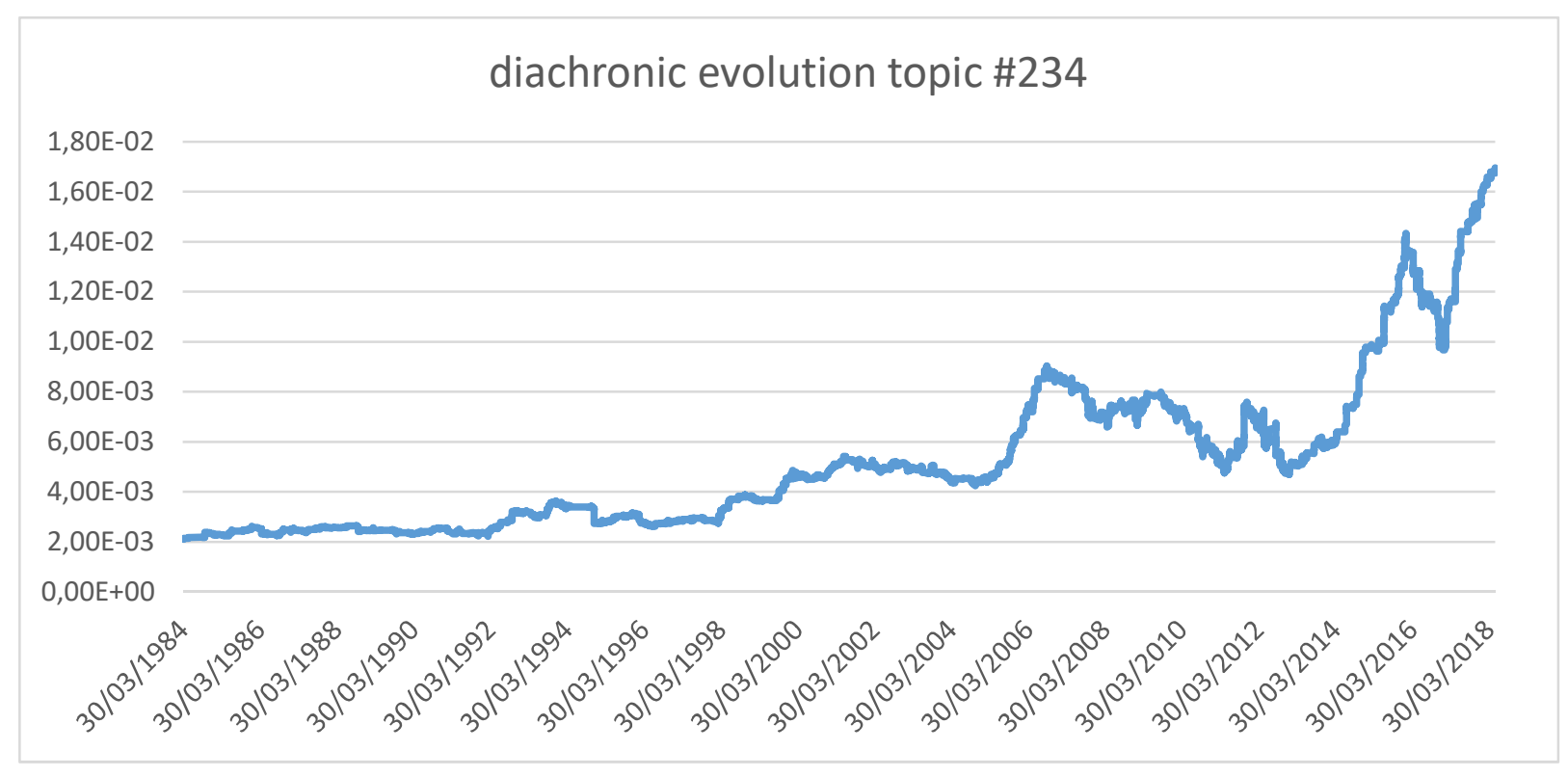

Graph 4: diachronic evolution of the political logic of political agency

In a different counterfactual scenario, which did not occur, the challengers of ACTA, TTIP, and CETA could have attempted to seize the social logic of political agency and used it to forcibly make the point that their alternative vision of EU trade policy is just as feasible be as the dominant view, given that the latter merely entails a different way of governing and intervening in global markets. Supplanting the neoliberal logics usually accompanying the social logic of political agency, and replacing them with an alternative project while maintaining the social logic political agency itself, would have constituted a powerful argument. In both these hypothetical cases, we would not have seen a decline in the social logic of political agency.

In fact, one could argue from a discourse-theoretical perspective that the increased awareness of contingency and openness triggered by the articulation of a bevy of political logics ought to have strengthened the social logic of political agency, as MEPs embraced the real and open choice before them. Yet the diachronic trend of topic \#235 between 2013 and 2016, shows that this was clearly not the case. Both among the centrist and centre-right parties favouring the EU's trade policy, and among the left-wing, green, and far-right parties 
favouring an alternative to the hegemonic paradigm, we observe a decline in the use of topic \#235 when comparing the low-point of the TTIP negotiations with the period preceding it (see table 2). The affirmation of the social logics of political agency decreased in intensity across the board, suggesting that the norm of belief in political agency receded.

\begin{tabular}{|l|l|l|}
\hline Party & $\mathbf{3 / 2 0 1 0}$ until 6/2013 & $\mathbf{7 / 2 0 1 3}$ until 10/2016 \\
\hline ALDE & 0,0253 & 0,016387 \\
\hline ECR & 0,014177 & 0,012491 \\
\hline EFDD & 0,024586 & 0,009441 \\
\hline EPP & 0,020293 & 0,018387 \\
\hline G/EFA & 0,015235 & 0,012853 \\
\hline GUE/NGL & 0,014689 & 0,009166 \\
\hline independents & 0,012187 & 0,011188 \\
\hline S\&d & 0,020392 & 0,016624 \\
\hline
\end{tabular}

Table 2: use of topic \#235 during and prior to the TTIP controversy

The reason why we see a decline in the confidence of MEPs in their institutional capacity to act, rather than an embrace of the choice before them, has to do with the concrete shape of the social logic of political agency. As I argued when interpreting this logic, it does not represent a genuinely 'ethical' relationship with the contingency of markets and their organization, that accepts and embraces the plurality of ways in which they can be governed. ${ }^{83}$ Such a logic would probably indeed have been strengthened and deepened by the articulation of new political logics and the dislocation of the extant structure. ${ }^{84}$ The social logic of political agency found in the context of the EP however, articulates a shallower 'ideological' belief in the institutional governance and management of markets. ${ }^{85}$ This 
capacity is evidently thrown in doubt in the face of stalwart opposition and large-scale street protest.

The fact that faith in political agency receded during the TTIP controversy must have had important strategic consequences for the political actors in the European Parliament, as this social logic was a cornerstone of parliamentary practice for years. First of all, it evidently made it far harder for proponents of free trade deals to realize their vision. It goes without saying that a climate of political optimism and belief in institutional agency is far more conducive of the closing ambitious international trade agreements, than times of pessimism and institutional powerlessness are.

A telling instance of how the declining faith in political agency paralyzed the European Parliament can be found in the repeated reference by social-democrat MEPs to their "willingness to accept a good TTIP." 86 This discourse involves identification with a very passive and reactive subject position, as the TTIP agreement is framed as something that lies beyond the control of the speaker. The claim that one is ready to accept something implies that what is to be accepted lies beyond one's control, and is imposed from an exterior position. David Martin, speaking on behalf of the social-democrats, said: "my group has been explicit since the outset of the TTIP debate that we want a good TTIP but that we are ready to reject a bad TTIP, and we stand by that position." ${ }^{87}$ This statement makes it sound as if the social-democrats have no influence on the outlook of TTIP, and on whether it will be 'good' or 'bad' - its MEPs can only react to what they see and evaluate what is put in front of them. This is a form of political positioning at odds with the social logic of political agency, and indicative of its decline.

However, by not seizing on the social logic of political agency, the opponents of ACTA, TTIP and CETA exposed themselves to a similar problem. The replacement of the neoliberal paradigm with a more progressive one requires a strong belief in the possibility for 
people to forge and construct themselves the world they live in. For such a belief to materialize, the social logic of small-p political agency existing within the EP would have to be amplified and expanded into a full-blown logic postulating the agency of democracy and the people ${ }^{88}$ rather than to be undone. While it is hard to realize ambitious trade deals when fate in the power of politicians is low, it is even harder to promote and implement a fundamentally and radically new vision of international trade.

From a discourse-theoretical analytic standpoint, it can be said that the proliferation of political logics created options for political change during each of the three episodes of politicization. However, declining belief in social logic of political agency rendered full-on paradigm change unlikely each time around too. In a way, the opponents of ACTA, TTIP, and CETA were victims of their own success each time, as their successful attempts to politicize EU trade policy overextended, and politicized a social logic that ought to be a building block for their alternative vision by rendering it possible to cast this vision as feasible and achievable. Hence, during the politicization of ACTA, TTIP and CETA, the EP each time found itself in a position where internal changes within the dominant neoliberal paradigm were plausible, but where any attempt to fundamentally alter the hegemonic paradigm was hampered by a lack of trust in the power of politics to shape the world and the economy. ${ }^{89}$

This leaves us with the question why confidence in political agency collapsed so monumentally during the TTIP controversy. Other dips in the graph showing the diachronic evolution of topic \#235 pale compared to the decline that can be observed between 2013 and 2016. A partial explanation is of course the scale of the street protests and civil opposition against TTIP. Hundreds of thousands of people took to the streets, more than three million people signed the call for a European Citizen's Initiative to "stop TTIP”, and a broad and politically diverse coalition of NGOs and civil society organizations expressed their opposition to the transatlantic trade deal. ${ }^{90}$ But this explanation at least partially constructs the 
symptom as the cause. Furthermore, the brunt of the street protests only took place in the summer of 2016, when according to the timeline of topic \#235, faith in political agency had already started to recover.

Looking at the rhetorical evolutions and changes in the corpus during the 2013-2016 period, two interesting transformations coincide with the decline of the social logic of political agency. First, there is a complete collapse of topic \#148, which comprises the discursive elements of a classic anti-capitalist political logic concerned with "multinationals", "workers", "profits", the consequences of "liberalisation", and "social rights".

$148 \quad 0,06773$ interests liberalisation social capital people multinationals countries workers against rights economic peoples resources big consequences sovereignty freetrade internationaltrade profits other

\section{diachronic evolution topic \#148}

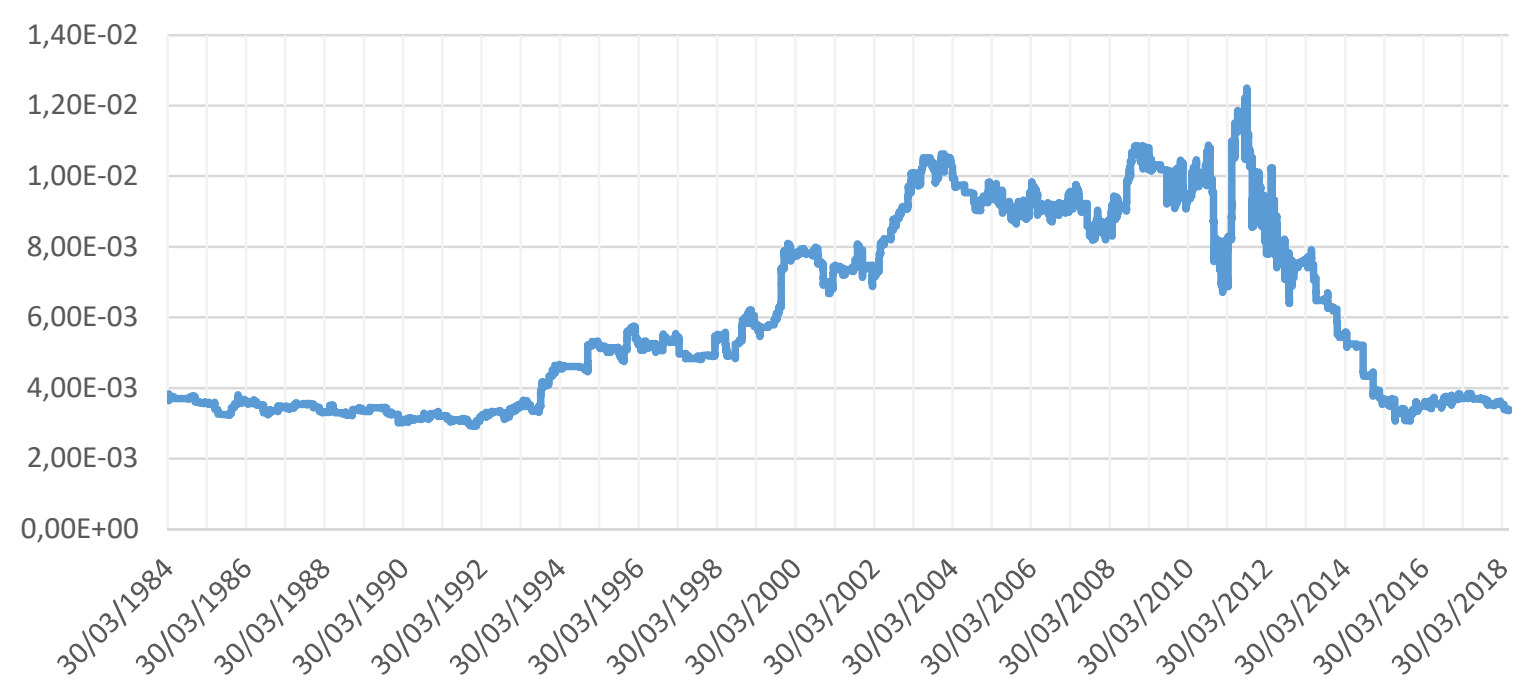

Graph 5: the diachronic evolution of the political logic of anti-capitalism (topic \#148)

At the same time, two topics which were up until that point negligible, skyrocketed. Topic \#33 and topic \#192, which both share a concern for transparency, access to information, 
public accountability, and generally speaking good governance, peak during the TTIP protests. The former is mainly focused on transparent and accountable government, with citizens having access to documents, information, and the institutions that represent them. The latter is focused on the governance of international trade in particular, and is frequently used to criticize the impact of TTIP on public procurement; TTIP's international dispute settlement system (ISDS), which creates a private court system to which only international investors have access; and its impact on the legislative freedom of national and authorities and governments.

$33 \quad 0,01463$ transparency commission citizens court european documents public information ombudsman auditors inquiry institutions committee ttip access office fraud negotiations administration cases

1920,01787 public ttip contracts publicprocurement isds procurement companies government national authorities transparency tender local gpa private services courts access court contract

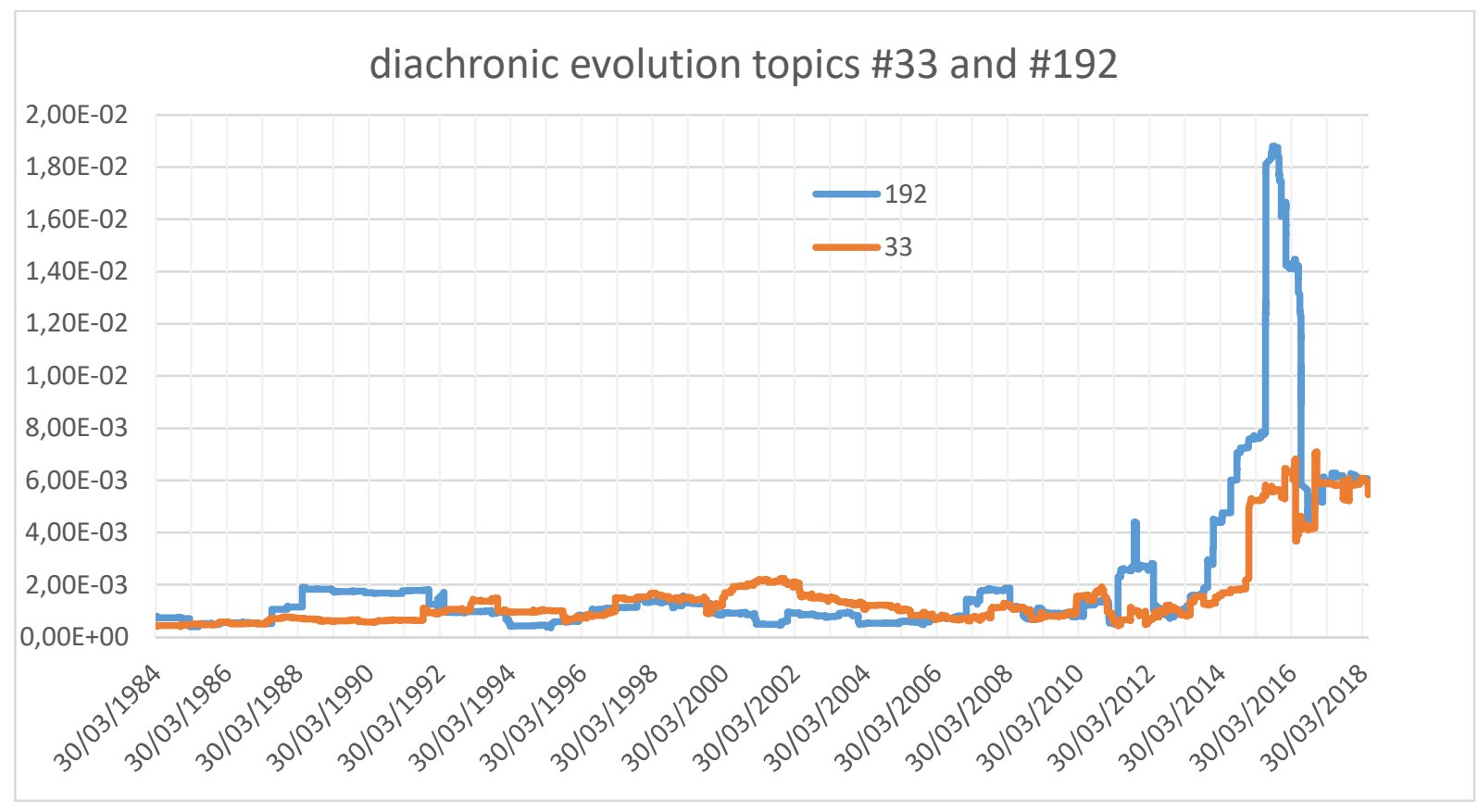

Graph 6: the diachronic evolution of the political logic of transparency (topics \#33 and \#192)

The role played in the TTIP protests by issues such as transparency, accountability, investor-state dispute settlement (ISDS), and the legislative 'chill' on domestic governance 
has been explored previously in the literature. ${ }^{91}$ Yet when we put this picture next to the simultaneous receding of a classic left-wing anti-capitalist discourse, it becomes clear that the manner in which the dominant free trade paradigm was contested in the European Parliament completely changed during the TTIP protests. The classic economic antagonism, that in its most extreme form cast the EU's trade policy as “an attack on grassroots rights, more exploitation, higher unemployment, greater poverty and more imperialist interventions to safeguard the profits of the monopolies", ${ }^{92}$ was abandoned in favour of what could be named a 'democratic' antagonism, which denounces "[t]he 'revolving door" practices in the European Commission" and "the lack of transparency and public participation in the TTIP negotiations." $" 93$

It would be an epistemological overreach to claim that this change in how the Commission's trade policies were contested was the sole cause or the decisive catalyst for the successful politicization of TTIP. For instance, the discourse of the alterglobalization movements of the late nineties already comprised 'democratic' elements, which is reflected by the modest rise of topic \#33 around the time of the 1999 Seattle protests. Yet it should nevertheless be remarked that the 'democratic' antagonism has several distinct strategic advantages over the 'economic' antagonism, that made it far more likely to have a strong impact within the discursive context of the European Parliament.

First of all, the use of signifiers like "transparency" and "citizens" and the critique of the governance of international trade speak to hegemonic block in EP far more than a rhetoric about "profits" and "multinationals" does. If signifiers like "profits" and "multinationals" are at all meaningful moments in the worldview of centre-right MEPs, they undoubtedly carry a connotation that diverges vastly from the anti-capitalist interpretation. Hence, political logics constructed around nodal points such as "profits" and "multinationals" by a progressive discourse are unlikely affect the social logics attached to these notions by right-wing MEPs. 
On the other hand, signifiers like "democracy", "transparency", and "accountability" are meaningful to nearly all political parties in the Parliament, and they are so in a similar fashion. While their precise meaning of course still differs according to political allegiance, the centrality of these signifiers to the debate within the EP makes political logics attached to them far more likely to resonate beyond the left of the hemicycle. The 'economic' antagonism politicizes social logics that only exist as regular patterns within the worldview of the left of the political spectrum, whereas the 'democratic' antagonism politicizes social logics that are established values for liberals, socialists, conservatives, greens, and Christian-democrats alike. This entails that the latter antagonism can re-articulate the hegemonic view of international trade more readily. Quite simply, demands on behalf of the "citizens" have a broader appeal within the EP than demands on behalf of the "working class".

One very concrete manifestation of this strategic advantage is visible in the diversity of the coalition that rallied under the banner of the 'STOP TTIP' movement. The articulation of a democratic antagonism that did not explicitly centre on opposition to capitalism made it possible to recruit allies that do not traditionally get involved in progressive economic politics. ${ }^{94}$ The rallying of consumer organizations and health insurers to the STOP TTIP cause was only possible because a democratic antagonism allows for the adoption of their demands and concerns into the counterhegemonic discursive chain, whereas an antagonism articulated around an anti-capitalist economic stance does not.

The final strategic advantage of the democratic antagonism over the economic antagonism revolves around how these two political logics relate to the social logic of political agency. The economic antagonism is based on the premise that the EU's trade policy represents the interests of capital and the multinationals. In this guise, the economic antagonism does not politicize the agency of MEPs - it does not contest their ability or 
capacity to govern international markets - it merely accuses MEPs of governing on behalf of the wealthy, rigging the game against the workers.

The democratic antagonism, reversely, does affect the social logic of political agency. Its focus on access to documents and information, transparency and accountability in the negotiations, and the legal framework of the agreement entails the politicization of the formal, institutional, and procedural aspects of the governance of international markets, rather than the actual content of this governance. Whereas a debate about economic models and whose interests they represent does not involve the social logic of political agency, the contestation of how policy-making and negotiations takes place does bring this logic into jeopardy. A heated discussion about the conduct of politicians and institutions and about how they go about their business could plausibly reduce the belief of these politicians in the legitimacy of and capacity for political action - and it appears that this was indeed the case.

In summary, between 2013 and 2016, opposition to the neoliberal free trade paradigm dominating the European Parliament was rearticulated around a 'democratic' antagonism that focused on the modalities of commercial governance (transparency, accountability, the procedures of policymaking), abandoning the earlier 'economic' antagonism which criticized the commercial model of international trade. This transformation allowed for the construction of a more resonant political logic that successfully spoke to the worldview embedded in the hegemonic paradigm, and for the creation of space in the counterhegemonic discursive chain for demands that were previously excluded from the narrower economic antagonism. Simultaneously, belief in political agency declined strongly, as the new political logic formulating a democratic antagonism politicized the social logic of political agency, shaking the belief of MEPs in their ability to govern and enact change in the global economy, thereby inadvertently creating a new obstacle to a more fundamental paradigm shift. 


\section{Concluding Reflections}

Evidently, these empirical findings are valuable in their own right, as they enrich our knowledge of how the contestation of free trade played out in the European Parliament over the last years and decades. They also provide a strong illustration of the points made by Springer and Dahlberg concerning the varied and complex nature of neoliberalism. ${ }^{95}$ The EP's consensus regarding the pro-active role that politicians do in fact have to play in the governance of global markets defies the classic conception of neoliberalism as a universal retreat of the state and a reduction of political interference to the benefit of free, selfregulating and self-sustaining markets. Finally, by doing justice to the specificity of how neoliberal governance is articulated, this study confirms Phelan's contention that a discoursetheoretical approach provides the literature on neoliberalism a way to by-pass the pitfall of subsumption. ${ }^{96}$

In these concluding thoughts, however, I mainly want to revisit the theoretical debate about the role of ideas in politics that opened this paper. The case study I developed here shows how a poststructuralist ontology differs from the more common constructivist approaches, and hence demonstrates its unique contribution to the ideational study of political economy. In the literature on EU trade policy, constructivist approaches have mostly focused on the actors, be they the European Commission, ${ }^{97}$ its officials, ${ }^{98}$ or commissioners, parliamentarians and individual politicians. ${ }^{99}$ These actors have ideas which motivate them towards certain goals; which they try to persuade other actors of; and which mutatis mutandis render them vulnerable to conviction by other actors.

In the poststructuralist approach operationalized here, ideas have a different ontological status. While they are articulated by subjects, they are not understood as an emanation of that person's personal thoughts. Instead, individual articulations are seen as instances of a wider discursive pattern - a logic. A discourse, within this perspective, is not something used by an individual to voice his ideas; it is an intersubjective constellation of 
subject positions that has the same ontological status as an idea. ${ }^{100}$ What this entails, is that poststructuralist approaches conceive discourses in a far more structural manner than constructivist approaches do. Turning then from structuralism to poststructuralism, ideational structures are conceived as simultaneously the setting for and the object of political struggles, rather than as a resource for political struggle. Ideas are no longer an ephemeral superstructures or explanatory one variable amongst many, instead, they are integral to the reproduction and contestation of the relations and conditions of production. ${ }^{101}$

This account points indirectly to the analytical added value of post-Marxist Discourse Theory: its poststructuralist conception of the theory of hegemony. Ideational change is for PDT not the result of individual persuasion, but of hegemonic politics. A discourse-theoretical approach to the study of ideas in politics concerns itself with the construction of an ideological common-sense, with how the extant ideational environment conditions the feasibility of political projects, with how the hegemonic structure maintains its dominance and is simultaneously open to contestation. Its account of how political logics relate to social logics tells us a story about how "the political game" may play out. ${ }^{102}$ Neoliberalism is, in such an account, no universal process that unfolds itself in a variety of ways, but an "impossible object", that only exists as the contingent outcome of the political game that gives rise to it. ${ }^{103}$

However, while like any form of social structuration, neoliberal formations are contingent and non-necessary, the sedimentation of social formations as social logics entails that not all attempts to change the world around us through political logics are equally feasible. ${ }^{104}$ I demonstrated for instance how the political logic formulating an economic antagonism was far less likely to politicize the social logic of political agency than the political logic formulating a democratic antagonism was. The politicization of the social logic 
of political agency in turn entailed that most political logics attempting a radical rearticulation of trade politics were unlikely to succeed.

This interpretation of Discourse Theory is what Martin Nonhoff refers to when he describes articulations as 'strategies'. ${ }^{105}$ "[A]rranging discursive elements across time and discursive space" is strategic because it has manifest political consequences, in the sense that it determines what the world around us looks like. ${ }^{106}$ In other words, if the political is primary, as Laclau and Mouffe postulate, then articulation is necessarily strategic. Herschinger points out that interpreting articulations as strategies "does not imply the presence of an intentional subject". ${ }^{107}$ She argues that strategies "do not exist outside of structure [...] A subject may have intentions in mind whenever a strategic intervention is made, yet the properties and effects of the strategy it employs will depend on many other factors: strategy is never simply a function of intention." This insight chimes with how I differentiated constructivism and poststructuralism earlier: constructivism offers an intentional account of political strategies, concerned with (disin)genuousness and persuasion, poststructuralism offers a structural account concerned with hegemony and the interaction of political and social logics in the construction of society. 


\section{Acknowledgments}

I am grateful to Jan Orbie, Ferdi De Ville, Niels Gheyle, Yelter Bollen, and the members of Centre for EU Studies of Ghent University for their political-economic comments, to

Christophe Verbruggen and Julie Birkholz for their methodological comments, and to Jason

Glynos, David Howarth, Tomas Marttila, Geert Jacobs, Marie Jacobs, and the members of the Centre of Ideology and Discourse Analysis of the University of Essex for their theoretical comments.

\section{Declaration of interest statement}

The author has no conflict of interest to declare. 


\section{References}

${ }^{1}$ Ferdi De Ville and Gabriel Siles-Brügge, "The role of ideas in legitimating EU trade policy: from the Single Market Programme to the Transatlantic Trade and Investment Partnership." In Handbook on the eu and International Trade, edited by Sangeeta Khorana and Maria Garcia, 243262. Cheltenham: Edward Elgar Publishing, 2018.

${ }^{2}$ Gabriel Siles-Brügge, "The power of economic ideas: a constructivist political economy of EU trade policy," Journal of Contemporary European Research 9, no. 4 (2013): 598-617; Ferdi De Ville and Jan Orbie, "The European commission's neoliberal trade discourse since the crisis: Legitimizing continuity through subtle discursive change," The British Journal of Politics and International Relations 16, no. 1 (2014): 149-167; De Ville \& Siles-Brügge, ideas in legitimating EU trade policy.

${ }^{3}$ Siles-Brügge, "The power of economic ideas".

${ }^{4}$ Oscar Larsson, "Using post-structuralism to explore the full impact of ideas on politics," Critical Review 27, no. 2 (2015): 174-197.

${ }^{5}$ Vivien Schmidt, "Taking ideas and discourse seriously: explaining change through discursive institutionalism as the fourth 'new institutionalism'," European political science review 2, no. 1 (2010): 1-25; Vivien Schmidt, "Speaking to the markets or to the people? A discursive institutionalist analysis of the EU's sovereign debt crisis," The British Journal of Politics and International Relations 16, no. 1 (2014): 188-209; Vivien Schmidt, "Theorizing ideas and discourse in political science: intersubjectivity, neo-institutionalisms, and the power of ideas," Critical Review 29, no. 2 (2017): 248-263.

${ }^{6}$ Colin Hay, "The interdependence of intra-and inter-subjectivity in constructivist institutionalism," Critical Review 29, no. 2 (2017): 235-247.

${ }^{7}$ Thomas Jacobs, "Poststructuralist discourse theory as an independent paradigm for studying institutions: Towards a new definition of 'discursive construction' in institutional analysis,” Contemporary Political Theory 18, no. 3 (2019): 382, 386-387

${ }^{8}$ Schmidt, "Taking ideas and discourse seriously", 3; Schmidt, "Theorizing ideas and discourse", 253.

${ }^{9}$ Oscar Larsson, “Advancing Post-Structural Institutionalism: Discourses, Subjects, Power Asymmetries, and Institutional Change," Critical Review 30, no. 3-4 (2018): 334-337; Larsson, "Using post-structuralism", 189-191; Larsson, "Advancing post-structuralist institutionalism", 334337; Jacobs, "independent paradigm”, 387-388.

${ }^{10}$ Larsson, “Advancing Post-Structural Institutionalism”, 325-346.

${ }^{11}$ Jacobs, "independent paradigm”, 382, 386-387, 391; Larsson, “Advancing Post-Structural Institutionalism", 331-332.

${ }^{12}$ Jacobs, “independent paradigm”, 385.

${ }^{13}$ Larsson, “Advancing Post-Structural Institutionalism”, 194.

${ }^{14}$ Siles-Brügge, "The power of economic ideas", 599, 601.

${ }^{15}$ Siles-Brügge, "The power of economic ideas".

${ }^{16}$ De Ville \& Orbie, "European commission's neoliberal trade discourse".

${ }^{17}$ Niels Gheyle, Trade Policy with the Lights on, Doctoral dissertation, Ghent University (2019). 
${ }^{18}$ De Ville \& Siles-Brügge, "ideas in legitimating EU trade policy".

${ }^{19}$ Jan Orbie. "The European Union's Role in World Trade: Harnessing Globalization?” In Europe's Global Role: External Policies of the European Union, edited by Jan Orbie, 35-66. Farnham: Ashgate Publishing, 2008.

${ }^{20}$ Larsson, “Advancing Post-Structural Institutionalism”, 335

${ }^{21}$ Larsson, "Using post-structuralism”; Larsson, “Advancing Post-Structural Institutionalism”; Jacobs, "independent paradigm".

${ }^{22}$ ibid, 390.

${ }^{23}$ ibid, 390-391.

${ }^{24}$ Ernesto Laclau and Chantal Mouffe, Hegemony and socialist strategy: Towards a radical democratic politics. London: Verso (1985/2014): 108-109, 114 cited in Jacobs, “independent paradigm", 387.

${ }^{25}$ Schmidt, "Speaking to the markets", 194.

${ }^{26}$ Larsson, “Using post-structuralism”; Larsson, “Advancing Post-Structural Institutionalism”; Jacobs, "independent paradigm".

${ }^{27}$ ibid, 387-388.

${ }^{28}$ Larsson, "Using post-structuralism".

${ }^{29}$ Simon Springer, "Neoliberalism as discourse: between Foucauldian political economy and Marxian poststructuralism," Critical Discourse Studies 9, no. 2 (2012): 133-147.

${ }^{30}$ Lasse Thomassen, "Discourse and Heterogeneity." In Discourse, Culture and Organization, edited by Tomas Marttila, 43-61. Cham: Palgrave Macmillan (2019).

${ }^{31}$ Matthew Watson and Colin Hay, "The discourse of globalisation and the logic of no alternative: rendering the contingent necessary in the political economy of New Labour," Policy \& Politics 31, no. 3 (2003): 289-305.

${ }^{32}$ Amit Avigur-Eshel, "Encouraging Action in the Private Sphere: Demand-Side Practices in the Depoliticization of Economic Policy in Israel," Politics \& Policy 46, no. 1, (2018): 86.

33 ibid, p. 88

${ }^{34}$ E.g. Paul Hirst and Grahame Thompson, Globalization in Question. Cambridge: Polity (1996). For a discussion, see Huw Macartney, Variegated neoliberalism: EU varieties of capitalism and international political economy. London: Routledge, 2010.

${ }^{35}$ Mark Bevir, Democratic governance. New Jersey: Princeton University Press (2010).

${ }^{36}$ Springer, "Neoliberalism as discourse", 135.

${ }^{37}$ Neil Brenner, Jamie Peck, and Nik Theodore, "Variegated neoliberalization: geographies, modalities, pathways," Global networks 10, no. 2 (2010): 182-222.

${ }^{38}$ Macartney, Variegated neoliberalism, 63-83, 146-153

${ }^{39}$ Ibid., 5

${ }^{40}$ Sean Phelan, "The discourses of neoliberal hegemony: The case of the Irish Republic," Critical Discourse Studies 4, no. 1 (2007); 29-48; Sean Phelan, "Messy grand narrative or analytical blind spot? When speaking of neoliberalism." Comparative European Politics 5, no. 3 (2007): 328-338.

${ }^{41}$ Laclau and Mouffe, Hegemony and Socialist Strategy, 112 cited in Sean Phelan, "Neoliberalism, media and the political." Berlin: Springer, 2014: 31. 
${ }^{42}$ Nikolas Rose, Pat O’Malley, and Mariana Valverde, "Governmentality," Annual Review of Law and Social Science 2, no. 1 (2006): 83-104.

${ }^{43}$ E.g. respectively Yelter Bollen, The domestic politics of EU trade policy: the politicaleconomy of CETA and anti-dumping in Belgium and the Netherlands. Doctoral dissertation, Ghent University (2018); Tony Heron, and Pat Murray-Evans, "The EU and Africa: trade, development and the politics of inter-regionalism." In Handbook on the EU and International Trade, edited by Sangeeta Khorana and Maria Garcia, 206-223. Cheltenham: Edward Elgar Publishing, 2018.

${ }^{44}$ Phelan, "The discourses of neoliberal hegemony"; Phelan, "Messy grand narrative"; Phelan, Neoliberalism, media.

45 Jason Glynos and David Howarth, Logics of critical explanation in social and political theory. London: Routledge (2007): 166.

${ }^{46}$ Phelan, Neoliberalism, media, 58.

${ }^{47}$ Glynos and Howarth, Logics, 110, 165-166.

${ }^{48}$ Phelan, "Messy grand narrative", 328.

${ }^{49}$ Phelan, Neoliberalism, media, 32.

${ }^{50}$ Glynos and Howarth, Logics, 136.

${ }^{51}$ Ibid., 135.

${ }^{52}$ De Ville \& Siles-Brügge, "ideas in legitimating EU trade policy".

${ }^{53}$ Larrson, "Using post-structuralism".

${ }^{54}$ Watson and Hay, "The discourse of globalisation".

${ }^{55}$ De Ville \& Orbie, "European Commission's Neoliberal Trade Discourse"; De Ville \& SilesBrügge, "ideas in legitimating EU trade policy".

${ }^{56}$ Larsson, Using post-structuralism; Larsson, Advancing Post-Structural Institutionalism; Jacobs, independent paradigm.

${ }^{57}$ Laclau and Mouffe, Hegemony and Socialist Strategy; Glynos and Howarth, Logics; Jason Glynos and David Howarth, "Structure, agency and power in political analysis: Beyond contextualised self-interpretations," Political studies review 6, no. 2 (2008): 155-169. See Thomas Jacobs, "The Dislocated Universe of Laclau and Mouffe: An Introduction to PostStructuralist Discourse Theory," Critical Review 30, no. 3-4 (2018): 294-315 for an introduction to PDT.

${ }^{58}$ Laclau and Mouffe, Hegemony and Socialist Strategy, xiv.

${ }^{59}$ Glynos and Howarth, Logics.

${ }^{60}$ Ibid., 135.

${ }^{61}$ Jacobs, "independent paradigm".

${ }^{62}$ Glyn Daly, "The discursive construction of economic space: Logics of organization and disorganization," Economy and Society 20, no. 1 (1991): 79-102.

${ }^{63}$ Ibid., 79-90.

${ }^{64}$ Glyn Daly, "Radical(ly) political economy: Luhmann, postmarxism and globalization," Review of International Political Economy 11, no. (1) (2004): 1. 
${ }^{65}$ Ibid., 2, 13; Lincoln Dahlberg, "Capitalism as a Discursive System? Interrogating discourse theory's contribution to critical political economy," Critical Discourse Studies 11, no. 3 (2014): 260.

${ }^{66}$ Glyn Daly, "The Political Economy of (Im)possibility.” In International political economy and poststructural politics, edited by Marieke De Goede, 174-194. London: Palgrave Macmillan (2006): 177-178, 186.

${ }^{67}$ Thomas Jacobs and Robin Tschötschel, "Topic models meet discourse analysis: a quantitative tool for a qualitative approach," International Journal of Social Research Methodology 22, no. 5 (2019): 469-485.

${ }^{68}$ For an introduction to topic modelling, see Ted Underwood, "Topic modeling made just simple enough," The Stone and the Shell (2012). Available online at $<$ https://tedunderwood.com/2012/04/07/topic-modeling-made-just-simple-enough/>, last checked on 31/10/2019. On the compatibility of topic modelling and discourse analysis, see Anton Törnberg, and Petter Törnberg, "Muslims in social media discourse: Combining topic modeling and critical discourse analysis," Discourse, Context \& Media 13 (2016): 132-142; Jacobs and Tschötschel, "Topic models meet discourse analysis".

${ }^{69}$ The number of topics is chosen by the analyst. From the point of view of statistical optimization, 250 topics are too many. However, for discourse-analytic purposes, a higher number of topics is still recommended, as increasing the number of topics leads to the disambiguation of topics containing themes and issues into topics containing various discourses about these themes and issues (see Topic models meet discourse analysis).

${ }^{70}$ Marielle De Sarnez, ALDE, 16/2/2011

${ }^{71}$ Rolandas Paksas, EFDD, 21/11/2011

72 Reinhold Bocklet, EPP, 18/11/1992

${ }^{73}$ Rolandas Paksas, EFDD, 17/2/2011

${ }^{74}$ Didier Rod, G/EFA, 13/3/2003

${ }^{75}$ Gábor Harangozó, S\&D, 12/12/2006

${ }^{76}$ Glynos \& Howarth, Logics, 124.

${ }^{77}$ Ernesto Laclau,. New reflections on the revolution of our time. London: Verso (1990): 41-45; Glynos and Howarth, "Structure, agency and power".

${ }^{78}$ The graphs in this paper use a moving average, and show for each moment in time the average share of the 1.000 speeches most recent speeches up until and including that moment. The y-axis shows the relative share of the topic in the corpus (i.e., the percentage of words allocated to this topic).

${ }^{79}$ Avigur-Eshel, "Encouraging Action”, 84-109.

${ }^{80}$ Michael Geist, "The trouble with the anti-counterfeiting trade agreement (ACTA)," Review of International Affairs 30, no. 2 (2010): 137-147.

${ }^{81}$ Gheyle, Trade Policy with the Lights On

${ }^{82}$ Bollen, domestic politics of EU trade policy, 86-92.

${ }^{83}$ Glynos and Howarth, Logics, 110-113; 117-120.

${ }^{84}$ Glynos and Howarth, Structure, agency and power, 162-163.

${ }^{85}$ Glynos and Howarth, Logics, 110-117. 
${ }^{86}$ David Martin, S\&D, 15/07/2014

${ }^{87}$ David Martin, S\&D, 7/7/2015

${ }^{88}$ Laclau, New Reflections, 41-45; David Howarth, "Hegemony, political subjectivity, and radical democracy." In Laclau: a critical reader, edited by Simon Critchley \& Oliver

Marchart, 256-276. London: Routledge, 2004.

${ }^{89}$ Howarth, "Hegemony, political subjectivity", 265; Glynos and Howarth, "Structure, agency and power", 162-163.

${ }^{90}$ Gheyle, Trade Policy with the Lights On.

${ }^{91}$ Ibid.

92 Georgios Toussas, GUE/NGL, 27/9/2011

${ }^{93}$ Lynn Boylan, GUE/NGL, 15/1/2015

${ }^{94}$ Gheyle, Trade Policy with the Lights On.

${ }^{95}$ Dahlberg, "Neoliberalism as Discourse", 257-271.

${ }^{96}$ Phelan, "The discourses of neoliberal hegemony"; Phelan, "Messy grand narrative".

${ }^{97}$ De Ville and Orbie, “The European Commission's Neoliberal Trade Discourse”.

${ }^{98}$ Siles-Brügge, "The power of economic ideas".

${ }^{99}$ De Ville and Siles-Brügge, "ideas in legitimating EU trade policy".

${ }^{100}$ Larsson, "Using post-structuralism"; Larsson, “Advancing post-structuralist institutionalism”; Jacobs, "independent paradigm".

${ }^{101}$ Johannes Beetz and Veib Schwab, "Conditions and relations of (re) production in Marxism and Discourse Studies," Critical Discourse Studies 15, no. 4 (2018): 338-350.

${ }^{102}$ Ernesto Laclau, “Can immanence explain social struggles?” Diacritics 31, no. 4 (2001): 9.

${ }^{103}$ Laclau and Mouffe, Hegemony and Socialist Strategy, 112.

104 Jacobs, "independent paradigm".

${ }^{105}$ Martin Nonhoff, Lecture at Paris XII University, Créteil, July $1^{\text {st }} 2005$.

${ }^{106}$ Ibid., 16.

${ }^{107}$ Eva Herschinger, “'Hell is the other': conceptualising hegemony and identity through discourse theory." Millennium 41, no. 1 (2012): 76. 